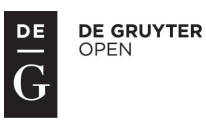

\title{
SENSitivity OF CZECH COMMERCIAL BANKS TO A RUN ON BANKS
}

\author{
Pavla Klepková Vodová ${ }^{1}$
}

\begin{abstract}
The aim of this paper is to thoroughly evaluate the sensitivity of Czech commercial banks to a run on banks. Our sample includes a significant part of the Czech banking sector in the period 2006-2013. We use three liquidity ratios that we stress via a stress scenario simulating a run on banks accompanied by a $20 \%$ withdrawal rate of deposits. We measure the impact of the scenario by the relative changes of these ratios. The results show that, in spite of a decrease in liquidity, most Czech banks would be able to finance such a scenario. The financial crisis influenced bank sensitivity to a run, but with a significant time lag. The severity of the impact of the bank run increases with the size of the bank; large banks are the most vulnerable. The resilience of banks is also determined by their strategy for liquidity risk management.
\end{abstract}

\section{Keywords}

Liquidity, Liquidity Risk, Scenario Analysis, Run on Bank, Czech Commercial Banks

\section{Introduction}

The fundamental role of banks is to transform short-term deposits into long-term loans. However, this transformation exposes them to liquidity risk. Each bank has to be liquid enough, which means each bank needs to have a sufficient buffer of liquid assets to be able to meet the demand for cash and other current receivables of its clients (e.g. when they want to withdraw their deposits or realize loan commitments) and also to be able to withstand a sudden liquidity outflow. Insufficient liquidity of a bank may lead to a situation wherein the majority of depositors intend to withdraw their funds, which will in turn cause a run on the bank. This situation is very dangerous even for healthy banks.

In fact, no bank is able to repay all its depositors their funds if there is a run on the bank. However, even though such a situation may be perceived as exceptional, extreme or simply

${ }^{1}$ Silesian University in Opava, School of Business Administration in Karviná, Univerzitní nám. 1934/33, 73340 Karviná, Czech Republic. E-mail: klepkova@opf.slu.cz. 
unexpected, it is still a plausible event. According to the recommendation of the Basle Committee for Banking Supervision, financial institutions should gauge their potential vulnerability to such events by conducting stress tests (BIS, 2000).

In spite of the fact that, as confirmed by the Czech National Bank (CNB, 2010), liquidity problems did not spill over into the Czech banking system, it could be very interested to test how well Czech banks would be able to withstand the sudden withdrawal of a large percentage of deposits, partly because the Czech banking sector experienced a bank run on - at that time the third-biggest bank - Investiční a Poštovní banka, in 2000 and on a number of small banks and credit unions in the nineties and at the beginning of the $21 \mathrm{st}$ century. The second reason is that bank runs have also occurred in developed economies in recent years, for example, the run on the fifth-largest mortgage lender in the United Kingdom, Northern Rock, in September 2007. It is evident that a potential bank run on Czech banks may be perceived as exceptional, extreme or simply unexpected, but it still a plausible event, which means that it meets all the conditions for stress testing.

The aim of this paper is therefore to thoroughly evaluate the sensitivity of Czech commercial banks to a run on banks. To fulfil this objective, we define the following fundamental research questions: (i) how sensitive are Czech banks to a possible bank run; (ii) which type of bank is the most vulnerable; (iii) did the financial crisis change banks' sensitivity; (iv) what is the impact of a possible bank run on different groups of banks; (v) what is the maximum volume of deposits that can be withdrawn from individual banks.

The paper is structured as follows. The next section provides a theoretical background for bank runs. Then we focus on methodology, data and the results of scenario analysis. The final section captures concluding remarks.

\section{Bank runs}

Banks have been always plagued by the problem of bank runs. Freixas and Rochet (1997) define a bank run as a situation wherein depositors observe large withdrawals from their bank, fear bankruptcy and respond by withdrawing their own deposits. Withdrawals in excess of the current expected demand for liquidity generates a negative externality for the bank experiencing the liquidity shortage, since they imply an increase in the bank's probability of failure.

Banks are vulnerable to runs that can lead to closure and liquidation because they issue liquid liabilities in the form of deposit contracts, but invest in illiquid assets in the form of loans. A banking panic then occurs when depositors at many or all of the banks in a region or a country attempt to withdraw their funds simultaneously (Allen and Gale, 1998).

The theoretical literature on bank runs is based mostly on the study of Bryant (1980) and the model of Diamond and Dybvig (1983). Both papers accentuate the fact that bank runs are self-fulfilling prophecies. Given the assumption of the costly liquidation of some assets, there are multiple equilibriums. If depositors believe that a banking panic will occur, it is optimal for each depositor to try to withdraw his funds. The bank will have to liquidate some of its assets at a loss. Those depositors who withdraw initially will receive more than those who wait (given the assumption of first-come, first-served). Anticipating this, all depositors have an incentive to withdraw immediately. Such a situation may be called 
an inefficient bank run. And, on the contrary, all agents withdraw their funds according to their consumption needs if all depositors believe no panic will occur (and other equilibrium exists).

Besides an inefficient bank run, efficient bank runs also exist. An efficient bank run is a bank run which is based on fundamental factors. Depositors who have information about an impending downturn in the business cycle may anticipate financial difficulties in the banking sector and try to withdraw their funds. Such behaviour will precipitate the crisis (Allen and Gale, 1998).

The severity of the impact of a bank run on the banking sector and the whole economy depends mainly on the reaction of the depositors after the deposit withdrawal. According to Kaufman (1988), depositors have three choices as to what to do with their withdrawals:

- they can redeposit their funds at another bank that is perceived to be safer; we call this a direct redeposit;

- they can purchase a security or real asset that is perceived to be safer (such as a treasury security), which is known as indirect redeposit; or

- they can hold the funds in cash outside the banking system, which will turn into a run on the banking system as a whole.

If only one bank or a small number of banks is being perceived as being in financial difficulty, depositors are likely to redeposit funds immediately in other banks that are believed to be safer. The net result is primarily a transfer of deposits and reserves from Bank A to Bank B with no change in aggregate reserves and deposits. Of course, regional contagion can occur. However, as long as depositors can identify some safe banks in which to redeposit their funds, the total deposits will remain basically unchanged and national or system-wide failure contagion can be ruled out.

Indirect redeposit means such a situation in which depositors use their deposits to purchase securities that they believe to be safer substitutes. The sellers of the securities then have the option to keep the funds in the bank, transfer them to another bank, or withdraw cash. Because security transactions are likely to be large, the seller of securities will probably try to find a safe bank instead of holding cash. This indirect redeposit scenario is almost equivalent to the previous one.

If both depositors and sellers of securities fear the insolvency of all banks, neither group will redeposit funds in other banks. In this case, the run is not on one bank but on the banking system as a whole. The flight to currency is equivalent to a drain of reserves from the banking system and will ignite multiple concretions in money and credit and increase the number and seriousness of bank fire-sale insolvencies. Unless the central bank injects reserves equal to the currency drain to offset the negative effects of the runs, bank failures will be contagious nationwide, destabilizing the financial sector, and adversely affecting aggregate economic activity. Which of the three scenarios described above is most likely to occur depends on the nature of the initial shock that causes the loss of confidence in one or more banks and the institutional arrangements in place at the time (Kaufman, 1988). As bank runs are typically perceived as costly and negative for the banking sector and the whole economy, most economists, and regulators in particular, try to find the best ways to 
prevent bank runs. One possibility is to establish a functional deposit insurance scheme. A major argument in favour of deposit insurance is that it maintains and promotes financial stability by preventing inefficient bank runs arising from asymmetric information and self-fulfilling prophecies (as in Diamond and Dybvig, 1983). According to Chu (2011), on the one hand, there is empirical evidence indicating that both good and bad banks are likely to suffer from massive deposit withdrawals during large-scale financial crises. But, on the other hand, many studies indicate that deposit insurance fails to maintain banking stability because of the moral hazard. Therefore, in spite of the fact that the deposit insurance fund began its operations as early as in 1 January, 1995, and the deposit insurance nowadays covers $100 \%$ of the deposit amount up to the limit of EUR 100,000, it can be useful to measure the sensitivity of Czech banks to a bank run (as it remains a plausible event).

\section{Methodology and data}

Scenario analysis is one possible tools with which to assess the vulnerability of banks to a bank run. We will therefore describe a scenario analysis based on selected liquidity ratios in the first part of this section, and then focus on the data used.

\section{Liquidity ratios}

Liquidity ratios are used for liquidity risk measurement and it is a stock-based approach which can help identify main liquidity trends (Vodová, 2013). Various authors provide various liquidity ratios. For the purposes of this paper, we will use the following three liquidity ratios: share of liquid assets in total assets, share of loans in total assets and share of loans in deposits.

$$
\mathrm{LIA}=\frac{\text { liquid assets }}{\text { total assets }} \times 100(\%)
$$

Equation 1 shows the principle of calculation for the share of liquid assets in total assets (LIA). It shows which part of the total assets can be readily converted to cash. Liquid assets consists of cash, balances with the central bank, receivables from credit institutions payable on demand and bonds issued by central governments and central banks. This ratio should give us information about the general liquidity shock absorption capacity of a bank. As a general rule, the higher the share of liquid assets in total assets, the higher the capacity to absorb liquidity shock, given that market liquidity is the same for all banks in the sample. Nevertheless, a high value for this ratio may be also interpreted as inefficiency. Since liquid assets yield lower income, liquidity bears high opportunity costs for the bank. Therefore it is necessary to optimize the relationship between liquidity and profitability.

$$
\mathrm{LOA}=\frac{\text { loans }}{\text { total assets }} \times 100(\%)
$$

The ratio LOA measures the share of loans in total assets (equation 2). The value of this ratio indicates what percentage of the assets of the bank is tied up in illiquid loans. The 
interpretation is therefore the opposite of the case in the previous indicator: the higher the value of this ratio, the less liquid the bank is. However, too low a value for this ratio may indicate that the bank does not provide sufficient loans. This could lower bank profitability.

$$
\mathrm{LOD}=\frac{\text { loans }}{\text { deposits }} \times 100(\%)
$$

The last liquidity ratio (equation 3) relates illiquid assets to liquid liabilities. The share of loans in deposits (LOD) has the same interpretation as the LOA ratio: the higher this ratio, the less liquid the bank is. This loan to deposit ratio also provides information as to which part of the loans provided to non-bank clients is financed from the deposits of non-bank customers. Values lower than $100 \%$ mean that loans are fully financed from client deposits. Values higher than $100 \%$ signal that the bank also needs other sources of funding, such as interbank loans or funds from debt securities issuance. Although a large proportions of client deposits are in the form of demand deposits, they are generally a stable source of funding. In terms of liquidity risk, banks should prefer a lower value for this ratio. A high value for the LOD ratio indicates that the bank is more vulnerable, especially in the event of market turbulence.

\section{Scenario analysis based on liquidity ratios}

Stress testing plays a complementary role in the risk management practices of banks. It can be used for many types of risks. Stress tests for market risk are well developed. The Basel Committee introduced stress testing in the Amendment to the Capital Accord to incorporate market risks (BIS, 1996): banks that use the internal models approach for meeting market risk capital requirements must have a rigorous and comprehensive stress testing program which should identify events or influences that could greatly impact banks. Stress testing is a key component of a bank's assessment of its capital position.

Stress testing is often also used for credit risk. According to Basel II rules (BIS, 2006), banks that adopt the internal approach for calculating credit risk capital requirements must also undertake stress testing. Stress tests should involve identifying possible events or future changes in economic conditions that could have unfavorable effects on a bank's credit exposure and assessment of the bank's ability to withstand such changes.

Stress tests for liquidity risk are used for a relatively short time. Liquidity stress test should identify and quantify the potential lack of liquidity for the specific stress scenario and determine how to close this lack at predefined costs. Three types of stress scenarios are usually applied: idiosyncratic, market, and a combination of both. The idiosyncratic scenario typically represents a simulation of an outflow of deposits or a decline in the rating of the bank. The market shock usually assumes a decline in the value of certain assets or disturbances in the money or credit markets. These two scenarios are accompanied by other macroeconomic shocks, such as the decline in economic activity, growth of loans in default or deterioration of the sovereign rating (Komárková et al., 2012).

During periods of financial distress, banks may especially be confronted with rapidly changing market situations. The concept of stress testing should answer the question "What 
would happen if market conditions suddenly change?" According to Breuer and Krenn (2000), stress scenarios should provide banks with answers to the following questions:

- What will be the loss in the event of each scenario?

- What is the worst scenario for each bank?

- What can we do to limit the losses incurred in the worst-case scenarios?

Krenn (2001) describes how to select stress scenarios. The selection of scenarios must be consistent with the risk profile of the bank. Stress scenarios should describe extraordinary market movements (such events that happen once or only a few times and can have dire consequences), but which are at the same time plausible. Plausibility means that stress scenarios have to appear credible. Bank stress tests need to cover a range of factors that can have an extraordinary impact on bank liquidity. Banks should consider historical scenarios. The selection of these is based on the assumption that future crises will resemble past crises. The fact that such scenarios already occurred increases their plausibility and acceptance. In addition, banks should also consider worst-case scenarios. This includes searching for scenarios which have not yet occurred but which can help banks not to underestimate the consequences of dramatic changes in market conditions.

Several central banks and other supervisory authorities have applied stress tests of liquidity, e.g. in the Netherlands (Van den End, 2008), the Czech Republic (Komárková et al., 2011) or Romania (Negrila, 2010). However, it is not possible to repeat their tests with publicly available information.

Therefore we will focus on other, less complex, studies which measured the impact of a selected scenario on selected liquidity ratios in the Austrian (Boss et al., 2004; Boss et al., 2007), Slovakian (Jurča and Rychtárik, 2006) or Luxembourg (Rychtárik, 2009) banking sector.

Among the above cited studies, six focused on the impact of a run on banks on bank liquidity. Komárková et al. (2011) simulated deposit withdrawals of an average of $11 \%$ of total deposits. Negrila tested the impact of the sudden drawing of $20 \%$ from deposits of individuals and $10 \%$ from deposits of corporate clients. Boss et al. (2004) stressed liquidity ratios by means of a scenario in which nonbank customers would withdraw $20 \%$ of their deposits; they continued their scenario analysis by testing the impact of the withdrawal of $50 \%$ of nonbank deposits (Boss et al., 2007). Jurča and Rychtárik (2006) considered the scenario of a decline in client deposits by 20\%. Rychtárik (2009) measured the sensitivity of Luxembourg banks to the withdrawal of $20 \%$ of client deposits.

Based on these studies and on available data, we will simulate a run on a bank which would result in the withdrawal of a certain volume of client deposits. We simulate a $20 \%$ withdrawal of deposits; this haircut is applied on total deposits, not taking into account agreed maturities of different types of deposits. This is how to model an outflow of primary sources from the bank. To calculate the stressed value of liquidity ratios, we have to deduct the volume of withdrawn deposits, i.e. $20 \%$ of client deposits, from liquid assets. The bank must use liquid assets to be able to repay deposits. At the same time, the volume of total assets is also decreasing as a result of this operation. We must also reduce the volume of deposits by $20 \%$, so we will work with only $80 \%$ of the original volume of deposits. 
Equations 4-6 capture these modifications:

$$
\begin{aligned}
& \mathrm{LIA}_{\mathrm{S}}=\frac{\text { liquid assets }-0.2 \times \text { deposits }}{\text { total assets }-0.2 \times \text { deposits }} \times 100(\%) \\
& \mathrm{LOA}_{\mathrm{S}}=\frac{\text { loans }}{\text { total assets }-0.2 \times \text { deposits }} \times(\%) \\
& \mathrm{LOD}_{\mathrm{S}}=\frac{\text { loans }}{0.8 \times \text { deposits }} \times 100(\%)
\end{aligned}
$$

As a next step, we will compare these stress values to the baseline values of the ratios. The percentage change of the values of individual ratios for each bank in the sample and each ratio will be calculated according to equation 7 :

$$
\mathrm{L}_{\mathrm{it}}=\frac{\mathrm{L}_{\mathrm{itS}}-\mathrm{L}_{\mathrm{itB}}}{\mathrm{L}_{\mathrm{itB}}} \times 100(\%)
$$

where $L_{i t}$ is a bank/ratio specific figure, i.e. the percentage change of the ratio for the bank $i$ in time $t$ and the scenario), $\mathrm{L}_{\mathrm{itS}}$ is the stress value and $\mathrm{L}_{\mathrm{itB}}$ is the baseline value of all ratios for all banks and all years in the sample. Following the methodology of Rychtárik (2009), we will calculate the median values for all liquidity ratios and for all banks. The results will show the magnitude of the relative changes between the stress and baseline values, which will enable us to find the most vulnerable banks. In order to find out whether there are any significant differences depending on the size of the bank, we will also calculate average values separately for individual group of banks (small, medium and large).

\section{Data used}

We used unconsolidated balance sheet data over the period 2006-2013, as obtained from the annual reports of Czech banks. Table 1 shows more details about the sample.

Table 1: Data availability

\begin{tabular}{|l|llllllll|}
\hline Indicator & 06 & 07 & 08 & 09 & 10 & 11 & 12 & 13 \\
\hline Total number of banks & 37 & 37 & 37 & 39 & 41 & 44 & 43 & 44 \\
Number of obsv. banks & 11 & 11 & 12 & 12 & 13 & 13 & 14 & 14 \\
Share of total assets (\%) & 70 & 70 & 68 & 70 & 70 & 77 & 71 & 73 \\
\hline
\end{tabular}

Source: author's processing

In spite of the relatively small number of banks in the sample, the data set includes a significant part of the Czech banking sector (around 70\% of total assets of the banking sector). Due to the homogeneity of the data set, we include only data from commercial banks. We abstract branches of foreign banks, mortgage banks, building societies and state banks with special purpose (Českomoravská záruční a rozvojová banka and Česká exportní banka). A detailed list of banks in the sample can be found in the Appendix. 


\section{Results and discussion}

The first part of this section shows the median values of the baseline and the stress values of the chosen liquidity ratios. The second part of this section focuses on differences among individual groups of banks. The last part analyzes the maximum amount of deposits that can be withdrawn from individual banks.

\section{Baseline and stress values of liquidity ratios}

The median values of the baseline and stress values of share of liquid assets in total assets (LIA) are presented in Figure 1. As a higher value for this ratio means higher liquidity, it is evident that the average liquidity of Czech banks is very good. Liquid assets amounted to $15-23 \%$ of total assets in certain years. The decrease of liquidity in 2007 was due to the decrease of balances with central banks and other banks. The second-lowest median value for this ratio was recorded in 2012. However, as the average value of this ratio for the Czech banking sector was $29.1 \%$ (CNB, 2013), it is evident that this decline was caused by the development of liquid assets in some banks, particularly LLBW Bank, UniCredit Bank and Raiffeisenbank, banks which had the lowest values for this ratio. In contrast, the maximum values were seen mainly at banks that have just started their business, such as Evropsko-ruská banka, Fio banka or Airbank. A relatively high buffer of liquid assets (mainly due to large interbank transactions) was also held by PPF banka.

Figure 1: Share of liquid assets in total assets (in \%)

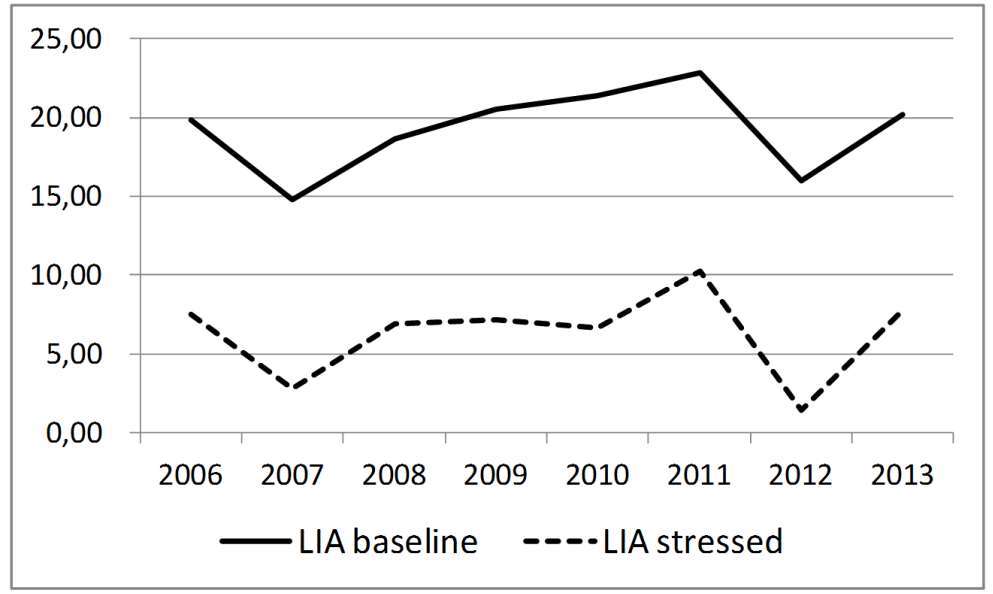

Source: author's calculation

As a higher value for the LIA ratio signals a better liquidity position of a bank, a lower stressed value for this ratio is therefore a signal of a liquidity outflow. Median values of the stressed share of liquid assets are positive for the whole analyzed period, which means that, in spite of a substantial decrease of liquidity, Czech banks on average would be able to finance a $20 \%$ withdrawal of client deposits. Of course, individual banks 
could have problems with such deposit withdrawals in some years (particularly Česká spořitelna in 2006-2008, ČSOB in 2006-2010, Equa bank in 2011-2013, GE Money Bank in 2007-2009, J\&T banka in 2012-2013, Raiffeisenbank in 2010-2013, LBBW Bank in 2012-2013 and UniCredit Bank in 2009, 2012 and 2013). Other banks would have had enough liquidity to fund the required deposit withdrawals, even in the crisis period.

Median values of the share of loans in total assets (LOA) are presented in Figure 2. The LOA ratio is an indirect way of measuring liquidity: it shows what percentage of the assets of the bank is tied up in illiquid loans. In terms of liquidity risk, lower values for this ratio are more appropriate. However, the differences between minimum and maximum values are really significant, indicating large differences in the business strategy of individual banks. The maximum values of the share of loans in total assets signals that banks are mostly focused on lending activity. This is true for GE Money Bank, Raiffeisenbank and Sberbank. Banks that prefer interbank transaction or trading with securities have a very low share of loans in total assets. This primarily refers to Československá obchodní banka and PPF banka. In addition, the minimum values for this ratio were also achieved by banks that started their business in particular years.

Figure 2: Share of loans in total assets (in \%)

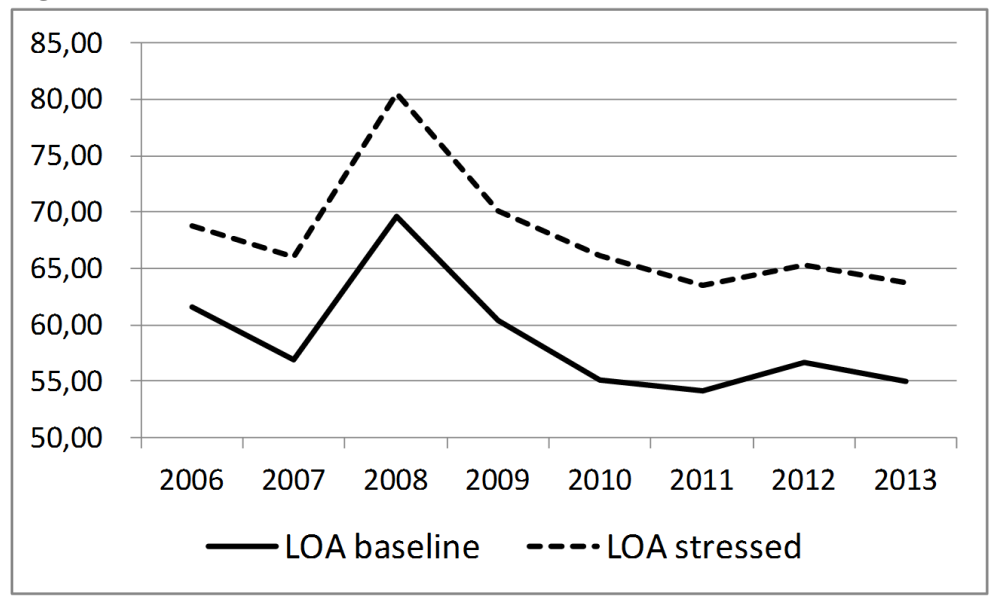

Source: author's calculation

The increase of the LOA ratio due to the stress scenario means that a bank run would reduce bank liquidity. The severity of the impact of a run on a bank is documented by the fact that the stress value of the LOA ratio is even higher than 100\% for GE Money Bank in 2007 and 2008. This means that GE Money Bank would not have had enough funds to cover loans already provided after an outflow of $20 \%$ of client deposits. In fact, this bank would not be able to fund a withdrawal of $20 \%$ of client deposits. As mentioned above, GE Money Bank strongly focuses on lending activity. Potentially, it is profitable to provide more loans, but the results of the scenario analysis illustrate that it is very important to 
properly balance the relationship between liquidity and profitability: a crisis situation may be far more difficult for banks which have a worse liquidity position due to their higher lending activity than for banks with less loans and a larger buffer of liquid assets.

The results of the median values of the share of loans in deposits can be found in Figure 3. The LOD ratio is very important for liquidity risk assessment. It provides information as to which part of the loans provided to non-bank clients is financed from client deposits. Values higher than $100 \%$ signal that the bank needs an additional source of funding, such as interbank loans or funds from debt securities issuance. As client deposits are considered a more stable source of funding, banks should prefer lower values for this ratio. Values higher than $100 \%$ signal that a bank is more vulnerable, especially during market turmoil. As in the case of the previous ratio, the higher the LOD ratio, the less liquid the bank is. The median values for this ratio indicate the very good liquidity position of Czech banks. The majority provide their loans from deposits. The exceptions are those banks with a value for this ratio which is higher than 100\%, mainly LBBW Bank, Raiffeisenbank and Sberbank. In some years, these banks have relied strongly on the interbank market.

Figure 3: Share of loans in deposits (in \%)

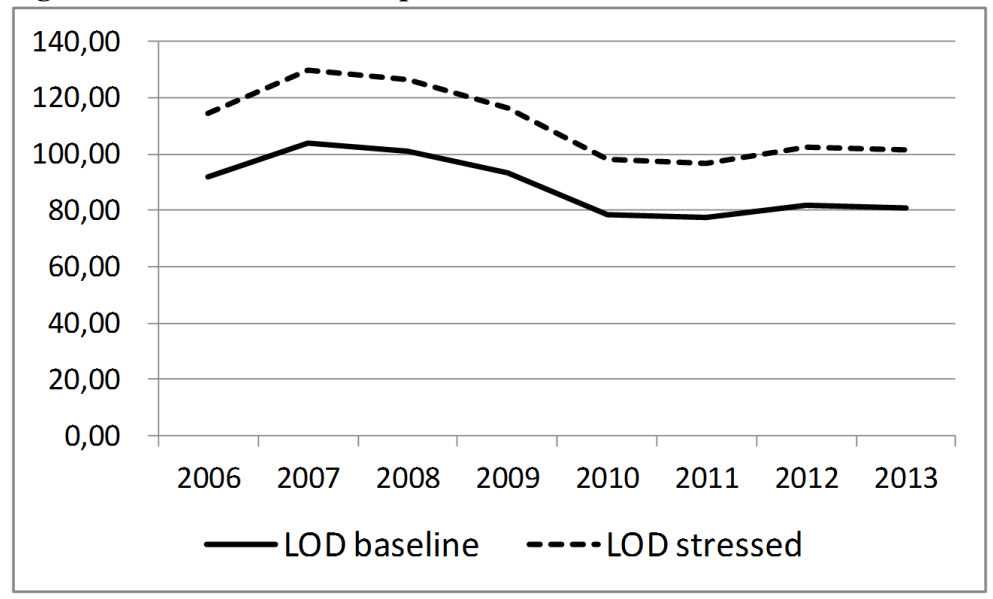

Source: author's calculation

The stress values of the LOD ratio show that, after a withdrawal of $20 \%$ of deposits, more banks would become dependent on additional sources of funding (besides the abovementioned three banks, this is also the case for GE Money Bank, Equa bank in 2006-2009, Evropsko-ruská banka in 2009-2010, J\&T banka in 2006-2008, ČSOB in 2011-2013 and Česká spořitelna in 2012-2013).

\section{Baseline and stress values of liquidity ratios by group of banks}

In order to find out whether the impact of the crisis in confidence on the interbank market differs according to the size of the bank, we divided the banks into three groups: small banks, medium banks and large banks. Following the methodology of the Czech National Bank (CNB, 2013), large banks are banks with total assets of more than CZK 250 billion, 
medium banks are banks with total assets of between CZK 50 billion and CZK 250 billion, and small banks are banks with total assets of less than CZK 50 billion. For each group of banks, we calculated average values of the baseline and the stress values of three ratios. The results can be found in Tables 2, 3 and 4 .

Table 2: Average values of the share of liquid assets in total assets by group of banks (in \%)

\begin{tabular}{|l|rrrrrrrr|}
\hline Group of banks & \multicolumn{1}{|c}{06} & \multicolumn{1}{c}{07} & \multicolumn{1}{c}{08} & \multicolumn{1}{c}{09} & \multicolumn{1}{c}{10} & \multicolumn{1}{c}{11} & \multicolumn{1}{c|}{12} & \multicolumn{1}{c|}{13} \\
\hline Small - LIA baseline & 47.8 & 28.9 & 43.5 & 35.7 & 40.6 & 36.2 & 29.7 & 31.4 \\
Small - LIA stressed & 43.2 & 21.9 & 36.2 & 28.7 & 30.8 & 25.4 & 16.1 & 17.5 \\
Medium - LIA baseline & 24.8 & 21.9 & 23.9 & 24.2 & 22.5 & 23.7 & 17.8 & 20.8 \\
Medium - LIA stressed & 12.7 & 9.7 & 12.2 & 11.8 & 9.5 & 11.2 & 4.0 & 7.3 \\
Large - LIA baseline & 21.2 & 17.5 & 16.7 & 15.8 & 15.6 & 20.1 & 13.0 & 15.7 \\
Large - LIA stressed & 8.2 & 4.3 & 4.3 & 3.5 & 3.7 & 9.1 & 1.2 & 4.2 \\
\hline
\end{tabular}

Source: author's calculation

Table 2 shows significant differences in the level of liquidity for each individual group of banks. The liquidity of small banks is substantially higher than the liquidity of medium and large banks. Therefore, even after a bank run, small banks are liquid enough. However, there are two exceptions among small banks - LBBW Bank (in 2012-2013) and Equa bank (in 2011-2013). As mentioned above, these banks are very vulnerable to a potential bank run. The liquidity of medium and large banks is significantly lower, which is consistent with the "too big to fail" hypothesis.

As for the whole group of banks, medium banks are most active in terms of providing loans to non-bank clients (Table 3). Small and large banks are less willing to provide loans, particularly Československá obchodní banka among large banks and Fio banka and Airbank among small banks. As a result of a bank run, the stress value of the share of loans in total assets is not too high for any group of banks.

Table 3: Average values of the share of loans in total assets by group of banks (in \%)

\begin{tabular}{|l|cccccccc|}
\hline Group of banks & 06 & 07 & 08 & 09 & 10 & 11 & 12 & 13 \\
\hline Small - LOA baseline & 49.1 & 66.8 & 48.3 & 54.7 & 47.5 & 48.7 & 51.2 & 51.8 \\
Small - LOA stressed & 53.4 & 73.4 & 55.2 & 61.0 & 55.4 & 56.9 & 61.0 & 62.3 \\
Medium - LOA basel. & 70.6 & 71.6 & 68.5 & 62.7 & 65.9 & 63.9 & 60.2 & 60.5 \\
Medium - LOA stress. & 81.9 & 82.7 & 79.0 & 72.8 & 76.9 & 74.4 & 70.2 & 70.7 \\
Large - LOA baseline & 46.1 & 47.1 & 51.9 & 49.3 & 48.6 & 55.7 & 51.7 & 53.5 \\
Large - LOA stressed & 53.8 & 54.9 & 60.2 & 57.2 & 56.2 & 63.5 & 58.9 & 61.0 \\
\hline
\end{tabular}

Source: author's calculation

Table 4: Average values of the share of loans in deposits by group of banks (in \%)

\begin{tabular}{|l|rrrrrrrr|}
\hline Group of banks & 06 & 07 & 08 & 09 & 10 & 11 & 12 & 13 \\
\hline Small - LOD baseline & 121 & 148 & 77.8 & 129 & 76.5 & 69.3 & 64.6 & 62.2 \\
Small - LOD stressed & 152 & 185 & 97.3 & 162 & 95.6 & 86.6 & 80.7 & 77.7 \\
Medium - LOD basel. & 104 & 108 & 107 & 92.2 & 93.4 & 91.9 & 84.4 & 83.6 \\
Medium - LOD stress. & 130 & 135 & 134 & 115 & 117 & 115 & 105 & 104 \\
Large - LOD baseline & 65.9 & 68.3 & 79.9 & 76.1 & 77.2 & 106 & 90.7 & 96.2 \\
Large - LOD stressed & 82.5 & 85.4 & 99.9 & 95.1 & 96.5 & 132 & 113 & 120 \\
\hline
\end{tabular}

Source: author's calculation 
There exist significant differences in the ways of financing lending activity among individual groups of banks (Table 4). The share of loans to deposits increases with the size of the bank: the LOD ratio is the highest for large banks and the lowest for small banks. This is completely in accordance with the values of the LIA ratio. Small banks hold a sufficient buffer of liquid assets, which would help them to withstand the crisis period. Large banks are much more vulnerable, which is also reflected by their higher dependence on other sources of funding.

Looking at the average impact of a bank run on the share of liquid assets in total assets for all banks in the sample, we can see that, due to the bank run, the decrease of bank liquidity gradually increased during the years analyzed (Table 5). It is evident that the financial crisis increased the sensitivity of Czech banks to a possible bank run. However, it is quite surprising that banks would have been the most vulnerable in the last two years. It seems that there exists a significant time lag. It is likely that the effects of the financial crisis on bank liquidity are rather indirect: the vulnerability of banks to sudden deposit withdrawal seems to have the same development trend as the average quality of the loan portfolio: with a growing share of nonperforming loans (CNB, 2014), the possible effects of bank runs worsen.

Table 5: Average decrease of the share of liquid assets in total assets by group of banks (in \%)

\begin{tabular}{|l|rccccccc|}
\hline Group of banks & \multicolumn{1}{|c}{06} & 07 & 08 & 09 & 10 & 11 & 12 & 13 \\
\hline Small banks & 9.6 & 24.4 & 16.7 & 19.5 & 24.1 & 29.7 & 45.7 & 44.4 \\
Medium banks & 48.9 & 55.8 & 49.2 & 51.2 & 57.9 & 52.7 & 77.3 & 65.0 \\
Large banks & 61.2 & 75.3 & 74.1 & 77.8 & 76.4 & 54.7 & 90.8 & 73.3 \\
All banks in the sample & 39.9 & 51.8 & 46.7 & 49.5 & 52.8 & 45.7 & 71.3 & 60.9 \\
\hline
\end{tabular}

Source: author's calculation

As can be seen from Table 5, the size of this impact differs significantly among individual groups of banks (the decrease of the share of liquid assets in total assets for individual banks is presented in Appendix). Again, this impact increases with the size of the bank, so the group of large banks would have the highest decline in the LIA ratio. Our conclusion, that large banks are most vulnerable to bank runs, is fully consistent with the findings of Jurča and Rychtárik (2006) for Slovak banks.

\section{Worst-case scenario for each bank}

Our aim is also to find out the maximum volume of deposits that can be withdrawn from individual banks, i.e. to find out the worst-case scenario for each bank. The threshold volume of deposits was calculated assuming that the bank can use the whole volume of liquid assets to meet the demands for cash of depositors. The data in Table 6 shows the ability of individual banks to cover deposit withdrawals, i.e. what is the maximum deposit withdrawal (in percent of deposits) which the banks would be able to survive. 
Table 6: Maximal deposits withdrawal (in \%)

\begin{tabular}{|l|rrrrrrrr|}
\hline Group of banks & 06 & 07 & 08 & 09 & 10 & 11 & 12 & 13 \\
\hline Airbank & & & & & & & 59 & 5 \\
Česká spořitelna & 19 & 15 & 19 & 26 & 35 & 31 & 20 & 28 \\
ČSOB & 14 & 8 & 16 & 20 & 14 & 77 & 71 & 72 \\
Equa bank & 157 & 109 & 43 & 48 & 54 & 10 & 19 & 17 \\
Evropsko-ruská banka & & & & 375 & 197 & 96 & 27 & 36 \\
Fio banka & & & & & 48 & 63 & 57 & 63 \\
GE Money Bank & 20 & 10 & 11 & 19 & 27 & 30 & 25 & 31 \\
J \& T banka & 24 & 23 & 24 & 34 & 31 & 33 & 14 & 15 \\
Komerční banka & 48 & 40 & 30 & 28 & 24 & 23 & 15 & 22 \\
LBBW Bank & 79 & 23 & 30 & 37 & 25 & 34 & 4 & 7 \\
PPF banka & 70 & 74 & 75 & 72 & 62 & 57 & 50 & 52 \\
Raiffeisenbank & 35 & 23 & 27 & 22 & 8 & 16 & 11 & 13 \\
Sberbank & 24 & 23 & 32 & 23 & 26 & 29 & 23 & 31 \\
UniCredit Bank & 30 & 29 & 31 & 19 & 20 & 27 & 5 & 6 \\
\hline
\end{tabular}

Source: author's calculation

As we can see, there are significant differences among banks. There exist banks that could only withstand the withdrawal of less than $10 \%$ of deposits, such as Airbank (in 2013), ČSOB (in 2007), LBBW Bank (in 2012-2013), Raiffeisenbank (in 2010) and UniCredit Bank (in 2012-2013). If customers would like to reduce their deposits more, the existence of these banks would be threatened because of insufficient liquidity. On the contrary, at least in some years, the depositors of the following banks would be able to withdraw more than 50\% of their deposits: ČSOB (in 2011-2013), Equa bank (in 2006, 2007 and 2010), Evropsko-ruská banka (in 2009-2011), Fio banka (in 2011-2013), LBBW Bank (in 2006) and PPF banka (during the whole analyzed period).

It is possible to find some common features for the groups of more and less resilient banks. We can generally say that the most vulnerable banks are those banks whose amount of client deposits is not sufficient to finance their activities. Therefore they need to use other sources of funding. Vulnerable banks also focus more on providing loans to non-bank customers; therefore they have a lower buffer of liquid assets. Liquidity is closely linked to profitability of banks. If banks prefer only to achieve maximum profitability, they provide relatively more loans to non-bank customers and they use more funds from the interbank market for the financing of their activities, which makes them much more vulnerable in case of crisis (which can be accompanied by, e.g. a bank run). On the contrary, the safest strategy is to hold a sufficient buffer of liquid assets (i.e. to have high value for the LIA ratio), to provide loans to non-bank customers reasonably and to finance lending activity mainly from client deposits.

\section{Conclusion}

The aim of this paper was to thoroughly evaluate the sensitivity of Czech commercial banks to a run on banks. We have used the scenario analysis for three liquidity ratios: share of liquid assets in total assets, share of loans in total assets and share of loans in deposits. We have calculated average and median values of baseline and stress types of these ratios, 
the percentage change of the share of liquid asset ratio and average values for individual groups of banks. The results enable us to answer the defined research questions:

How sensitive are Czech banks to a possible bank run? The results of the scenario analysis showed that, in spite of a decrease in liquidity (modelled by the withdrawal of $20 \%$ of client deposits), most Czech banks would be able to finance such a scenario. Some banks in some years would not have had a sufficient buffer of liquid assets to repay $20 \%$ of client deposits, particularly Česká spořitelna in 2006-2008, ČSOB in 2006-2010, Equa bank in 2011-2013, GE Money Bank in 2007-2009, J\&T banka in 2012-2013, Raiffeisenbank in 2010-2013, LBBW Bank in 2012-2013 and UniCredit Bank in 2009, 2012 and 2013. For these banks, in these years, a bank run could have had fatal consequences and could have threatened the very existence of these banks.

Which type of bank is the most vulnerable? The resilience of banks is determined mainly by their liquidity risk management strategy. Banks that prefer profitability and focus mainly on high lending activity, financed by funds from the interbank market or other alternative sources of funding and which have a relatively small buffer of liquid assets, are the most vulnerable. On the contrary, those banks focusing primarily on liquidity (i.e. banks with a higher buffer of liquid assets, reasonable lending activity financed mainly by client deposits) are much safer.

Did the financial crisis change banks' sensitivity? We have found that the financial crisis influenced bank sensitivity to bank runs. However, this impact is significantly lagged, as it is probably connected with the worsening quality of the loan portfolio.

What is the impact of a possible bank run on different group of banks? The analysis showed significant differences in the level of liquidity in individual group of banks: small banks are much more liquid than medium and large banks. Also, the severity of the impact of the bank run increases with the size of the bank; large banks are the most vulnerable.

What is the maximum volume of deposits that can be withdrawn from individual banks? This volume significantly differs among banks. Depositors of some banks are able to withdraw more than $50 \%$ of their deposits (this is the case mainly for PPF banka, Fio banka and Evropsko-ruská banka), on the contrary, some banks only have enough liquidity to cover a deposit withdrawal lower than 10\% (particularly LBBW Bank and UniCredit Bank).

\section{Acknowledgements}

This paper was prepared with the financial support of the Czech Science Foundation (Project GAČR 13-03783S: Banking Sector and Monetary Policy: Lessons from New EU Countries after Ten Years of Membership). 


\section{References}

Allen, F.; Gale, D. (1998). Optimal Financial Crises. The Journal of Finance, 53(4), 1245-1284.

BIS. (1996). Amendment to the Capital Accord to Incorporate Market Risks. Basel: Bank for International Settlements.

BIS. (2000). Stress Testing by Large Financial Institutions: Current Practice and Aggregation Issues. Basel: Bank for International Settlements.

BIS. (2006). International Convergence of Capital Measurement and Capital Standards. A Revised Framework. Basel: Bank for International Settlements.

Boss, M.; Fenz, G.; Krenn, G.; Pann, J.; Puhr, C.; Scheiber, T.; Schmitz, S. W.; Schneider, M.; Ubl, E. (2007). Stress Tests for the Austrian FSAP Update 2007: Methodology, Scenarios and Results. In Financial Stability Report, 68-92. Vienna: Oesterreichische Nationalbank.

Boss, M.; Krenn, G.; Schvaiger, M.; Wegschaider, W. (2004). Stress Testing the Austrian Banking System. Österreichisches Bankarchiv, 52(11), 841-852.

Breuer, T.; Krenn, G. (2000). Identifying Stress Test Scenarios. Fachhochschule Vorarlberg and Oesterreichische Nationalbank Working Paper.

Bryant, J. (1980). A model of reserves, bank runs, and deposit insurance. Journal of Banking and Finance, 4(4), 335-344.

CNB. (2010). Financial Market Supervision Report 2009. Praha: Czech National Bank. CNB. (2013). Financial Market Supervision Report 2012. Praha: Czech National Bank.

CNB. (2014). Core and encouraged financial soundness indicators (unconsolidated). Retrieved November 2, 2014, from http://www.cnb.cz/en/supervision_financial_market/aggregate_information_financial_sector/financial_soundness_indicators/fsi_ukazatele_nekons. html.

Diamond, D.; Dybvig, P. (1983). Bank runs, deposit insurance, and liquidity. Journal of Political Economy, 91(3), 401-419.

Freixas, X.; Rochet, J. C. (1997). Microeconomics of Banking. Massachusetts: Massachusetts Institute of Technology.

Chu, K. H. (2011). Deposit Insurance and Banking Stability. Cato Journal, 31(1), 99-117. Jurča, P.; Rychtárik, Š. (2006). Stress Testing of the Slovak Banking Sector. BIATEC, 14(4), 15-21

Kaufman, G. (1988). Bank Runs: Causes, Benefits and Costs. Cato Journal, 7(3), 559-595. Komárková, Z.; Geršl, A.; Komárek, L. (2011). Models for Stress Testing Czech Banks' Liquidity Risk. Working Paper Series of Czech National Bank, 11.

Komárková, Z.; Komárek, L.; Jakubík, P. (2012). Zranitelnost českého bankovního sektoru. Studie národohospodářského ústavu Josefa Hlávky č. 10. Praha: Národohospodářský ústav Josefa Hlávky.

Krenn, G. (2001). Stress Testing by Austrian Banks. In Financial Market Stability Report, 108-116. Vienna: Oesterreichische Nationalbank.

Negrila, A. (2010). The Role of Stress-test Scenarios in Risk Management Activities and in the Avoidance of a New Crisis. Theoretical and Applied Economics, 17(2), 5-24. 
Rychtárik, Š. (2009). Liquidity Scenario Analysis in the Luxembourg Banking Sector. BCDL Working Paper, 41.

Van den End, J. W. (2008). Liquidity Stress-Tester: A macro model for stress-testing banks' liquidity risk. DNB Working Paper, 175.

Vodová, P. (2013). Liquidity risk of banks in the Visegrad Countries. An empirical analysis of bank liquidity, its determinants and liquidity risk sensitivity. Saarbrücken: Lambert Academic Publishing. 
DOI: 10.1515/danb-2015-0006

\section{Appendix}

Table A: Decrease of the LIA ratio due to a bank run for all banks in the sample (in \%)

\begin{tabular}{|l|rrrrrrrr|}
\hline Group of banks & 06 & 07 & 08 & 09 & 10 & 11 & 12 & 13 \\
\hline Airbank & & & & & & & 18.5 & 26.3 \\
Česká spořitelna & 104 & 131 & 103 & 71.0 & 49.9 & 56.3 & 99.5 & 64.3 \\
ČSOB & 140 & 263 & 125 & 99.9 & 145 & 21.3 & 22.8 & 22.5 \\
Equa bank & 5.1 & 10.6 & 38.2 & 34.4 & 25.7 & 215 & 104 & 119 \\
Evropsko-ruská banka & & & & 2.3 & 4.2 & 9.9 & 68.7 & 44.7 \\
Fio banka & & & & & 28.9 & 16.7 & 20.3 & 15.7 \\
GE Money Bank & 98.1 & 215 & 187 & 101 & 69.0 & 60.4 & 75.8 & 56.4 \\
J \& T banka & 78.6 & 82.7 & 76.6 & 49.9 & 56.5 & 51.9 & 148 & 133 \\
Komerční banka & 28.7 & 38.1 & 59.5 & 63.3 & 79.4 & 80.9 & 136 & 87.3 \\
LBBW Bank & 18.4 & 85.6 & 60.2 & 47.6 & 73.7 & 51.5 & 518 & 313 \\
PPF banka & 15.8 & 13.7 & 12.8 & 16.1 & 20.8 & 23.3 & 29.9 & 27.6 \\
Raiffeisenbank & 50.2 & 81.3 & 68.1 & 87.9 & 269 & 128 & 182 & 156 \\
Sberbank & 78.1 & 84.2 & 58.1 & 85.0 & 73.7 & 64.6 & 83.0 & 58.7 \\
UniCredit Bank & 60.2 & 62.9 & 57.8 & 103 & 95.8 & 67.7 & 407 & 336 \\
\hline
\end{tabular}

Source: author's calculation 